\title{
Influence of big data and analysis of orientation effect on firm performance
}

Stefanny Magdalena Susanto

Stefannymagdalena55@gmail.com

Kinerja perusahaan yang baik bisa dinilai dari berbagai pendekatan dan teori yang mereka terapkan ke perusahaan mereka, salah satunya adalah perusahaan menggunakan kolaborasi strategis untuk mengurangi biaya dan meningkatkan produktivitas melalui kemampuan teknologi, pengetahuan, dan sumber daya (Moaniba, Su, \& Lee, 2020). Oleh karena itu, berdasarkan pandangan yang berbasis sumber daya, Big Data Resource diyakini dapat meningkatkan kinerja perusahaan dengan menambah kapabilitas perusahaan yang diarahkan ke pasar (Suoniemi, Waarden, Munzel, Zablah, \& Straub, 2020). Perusahaan yang terjun langsung ke pasar dapat menunjukkan kinerja yang lebih baik secara keseluruhan dilihat dari baik dan buruknya suatu perusahaan tersebut di berbagai bidang seperti masyarakat, lingkungan, hak asasi manusia, dan perlakuan perusahaan terhadap karyawan (Leong \& Yang, 2020). Karena kinerja perusahaan sangat terlihat oleh stakeholders, hal ini dapat berfungsi sebagai indikasi mengenai kemampuan perusahaan untuk mempertahankan kinerja keseluruhan dan menciptakan nilai (value) perusahaannya di masa depan (Salaiz, Evans, Pathak, \& Vera, 2020).

Strategic Orientation pada (Pratono, 2016) berpengaruh secara langsung terhadap firm performance suatu perusahaan. Dengan memanfaatkan Information Technology (IT), Perusahaan dapat mengembangkan keahliannya di berbagai sektor termasuk aliansi, pengembangan produk, pemasaran, dan merger. Variabel yang digunakan untuk penelitian dalam (Pratono, 2016) adalah Firm Performance, Strategic Orientation, dan Technological Turbulence. Sedangkan (Pratono, 2019) memanfaatkan Green Entrepreneurial Orientation (GEO) dan Market Orientation dalam mencapai Sustainable Competitive Advantage suatu perusahaan. Variabel yang digunakan (Pratono, 2019) dalam penelitiannya meliputi Entrepreneurial Orientation, Market Orientation, Inter-Organizational Learning, dan Sustainable Competitive Advantage. Sehingga bisa disimpulkan bahwa (Pratono, 2016) dan (Pratono, 2019) menggunakan variabel yang berbeda dalam penelitiannya. Kesamaan dari kedua jurnal tersebut adalah keduanya sama-sama menggunakan metode subjektif dalam pengumpulan data yaitu dengan pembagian kuisioner kepada koresponden. Selain cara pengumpulan data, keduanya juga sama-sama memanfaatkan sumber daya (resource) dalam mengukur kinerja perusahaannya. 


\section{Bibliography}

Leong, C. K., \& Yang, Y. C. (2020). Market competition and firms' social performance. Economic Modelling, 91, 601-612.

Moaniba, I. M., Su, H.-N., \& Lee, P.-C. (2020). Geographic distance between co-inventors and firm performance: Themoderating roles of interfirm and cross-country collaborations. Technological Forecasting \& Social Change, 157, 70-120.

Pratono, A. H. (2016). Strategic orientation and information technological turbulence : Contingency perspective in SMEs. Business Process Management Journal, 22(2), 368-382.

Pratono, et al. (2019). Achieving sustainable competitive advantage through green entrepreneurial orientation and market orientation: The role of inter-organizational learning. The Bottom Line, $32(1), 2-15$.

Salaiz, A., Evans, K., Pathak, S., \& Vera, D. (2020). The impact of corporate social responsibility and irresponsibility on firm performance: New insights to an old question. Organizational Dynamics, $49(2), 1-8$.

Suoniemi, S., Waarden, L. M., Munzel, A., Zablah, A. R., \& Straub, D. (2020). Big data and firm performance: The roles of market-directed capabilities and business strategy. Information \& Management, 57(7), 21-28. 